\title{
Recent Aggravation of Export Earnings in Bangladesh: Is This an Outcome of Export Subsidence of RMG Sector Due to COVID-19 Outbreak?
}

\author{
Naimur Rahman \\ naimur.rahman@bup.edu.bd \\ Lecturer, Department of Economics, Bangladesh University of Professionals (BUP), Mirpur Cantonment, Dhaka-1216, Bangladesh.
}

\begin{abstract}
:
Bangladesh has the $2^{\text {nd }}$ largest economy in term of purchasing power parity in South Asia after India. Bangladesh is also considered as one of the fastest growing middle-income countries with a market based mixed economy. Despite of trade deficit in the current account of the balance of payment, the country has been recognized as one of the key destinations of foreign direct investment. Availability of cheap labor made the cost of production lower which makes it possible to attract foreign buyers. Export oriented RMG sector has made a huge contribution in the economy of Bangladesh. Readymade garments have been the key source of export earnings with its accolades in the foreign market. This sector also provides a greater number of job creation especially for female workers. Current pandemic outbreak has raised an unfavorable situation in the RMG sector due to the lockdown in many developed countries, especially European countries which adversely affects the total export earnings of Bangladesh. Because of that, many factories have shut down their production with a huge extinction of foreign demand for RMG products. This voluminous impact of COVID-19 in the export earning capability of readymade garments industry has shifted the trade balance into an unstable situation to create short term alarm in the economy.
\end{abstract}

Key words: Balance of payment, Trade balance, Readymade garments (RMG), Export, Import, COVID-19

\section{Introduction:}

Bangladesh is apprehended as one of the promising countries among all developing countries. Export earnings counted as one of the key factors to metering the trade balances in the current account of a country's balance of payment. Bangladesh earned the place to be the second largest exporter to European Union through gaining 12 percent of its market share in fiscal year 2012-13. It had a significant market share of export in US market which was accounted to be 4.6 percent Asian Development Bank, 2013). Readymade garment has been the prominent contributor in the export earnings of Bangladesh. Total export earnings from RMG sector was calculated to be 83.49 percent of the total export earnings of Bangladesh in fiscal year 2017-18 (Export Promotion Bureau, 2019). RMG sector generates more than 4 million employment opportunities in 2017-18 fiscal year which feed a significant portion of the labor force of Bangladesh (BBS, 2019). The extensive dominance of total export earnings on RMG export has made the recent flow of export earnings downcast due to the recent pandemic situation of COVID-19, which affects awfully the RMG sectors with the forced shut down of more than 2000 factories and cancellation of more than 900 million of RMG products following by the 2.7 million affected labor force in RMG sector creating a great disquiet in the economy of Bangladesh (BGMEA, 2020).

\section{Objective:}

i. To identify the trend of export earnings of Bangladesh

ii. To identify the pattern of readymade garment industry of Bangladesh

iii. To examine the relationship between RMG export earnings and total export earnings of Bangladesh

iv. To analyze the effect of COVID-19 on readymade garments export growth rate. 


\section{Literature review:}

According to IMF, Bangladesh had a per capita income of US\$1906 in 2019, along with a GDP of \$317 billion. Industrial sector has been the dominant contributor for country like Bangladesh since we have moved from low income to middle income status. RMG industry in Bangladesh is an export-oriented sector, with 95 percent of the woven and 90 percent of the knit exports to the foreign markets (Bhattacharya et.al., 2002). Besides that, RMG sector has been a significant contributing sector for foreign export revenue, thus creating an important position on the economy of Bangladesh (Robbani, 2000). Total export of RMG of Bangladesh was about 30614.76 million US\$ from the total export of 36668.17 million US\$ which contributed 83.49 percent of the total export earnings of Bangladesh in year 2017-18 (Export Promotion Bureau, EPB, 2018). With this, RMG sector contributes to broaden the economy of Bangladesh. The exports of RMG of Bangladesh to other countries like India, China, Japan, Canada, Turkey, Australia, USA have been expanding with the passage of time. The journey of RMG sector started in late 1970s as a nontraditional export sector in a very small manner (Rehman \& Hundker, 2001). The first joint venture garment factory in Bangladesh was Desh garment in association with Daewoo, a South Korean company (Rock, 2001). The very first consignment was sent to USA in 1978 by Reaz Garments Ltd. worth 69,000 USD. Bangladeshi entrepreneurs slowly got themselves familiar with world market of apparel and soon achieved experiences in mobilization of resources to export oriented RMG industries. Because of the cheap sources, foreign buyers found Bangladesh a very attractive place to trade with and in some cases provided credit under special arrangements. With a view to importing quality fabric and basic raw materials, there was an introduction of letter of credit facilitated by the local banks (Chowdhury et.al., 2014). Within 20 years of time, RMG exports were reached to 4.5 billion USD showing an exclusive growth rate which settled a strong foundation of RMG sector (Adnan et.at., 2015). Bangladesh had 4.6 percent of market share of export to US market (Asian development bank, 2013).

The growth of the RMG sector helped to have a positive effect on macroeconomic balances along with maintaining a sustainable trade deficit. Trade deficit declined from around 10 percent to 5.5 percent in the early 1980s (Rahman, 2002). There were about 5876 industries in 2012-13 and 4222 industries in 2013-14 reported by BGMEA (2015). At present, according to BGMEA (2019), total number of garments factories have reached to 4621 in year 2018-19. Bangladesh export earnings is hugely dependent on RMG since the time we started exporting our RMG products to abroad. Percentage of RMG to the total export earnings was not significant at the beginning. It was only 3.89 percent in year 1983-84 but suddenly found its flow in year 1987-88 when RMG's contribution to the total export earnings was 35.24 percent. Since then its contribution has been shown an upward trend reached to 83.49 percent of total export earnings in year 2017-18 (Export Promotion Bureau, EPB, 2019). Bangladesh ranks $8^{\text {th }}$ in the world with a total population of 180 million people. Despite of having a huge population, Bangladesh manage to achieve growth and development by creating enough employment opportunities and garment sector plays an important role to provide a significant number of employment opportunities. There were 134 factories in 1983-84 employed 0.04 million people which rose to 4.0 million workers who was given job by 4000 garment factories in 2013-14 where 3.20 million were women which was 80 percent of employment in RMG. The number of factories has increased to 4560 in 2017-18 while maintaining 4.0 million employment (BGMEA, 2019). This sums up the fact that, RMG sector has been a hub of creating job for both male and female workers. The participation rate of female workers also postulates the women empowerment of Bangladesh. Participation of women which constitute 90 percent of the workforce has been the dynamic festure of RMG sector in Bangladesh. Inhuman working conditions in developing country like Bangladesh led the way of the creation of the Council of Economic Priorities Accreditation Agency in 1997 (Akter et. al., 2010). But skill of the workers in RMG sector has always been a core issue to worry about the growth of this sector as the quota system in 2005 creates a competition for Bangladesh from countries like India and China especially. Bangladesh lack behind because of the unskilled labor in the RMG sector. Unskilled labor having lower productivity increases the production cost causing the price of the product to be on the higher side (Chowdhury et.al., 2005).

Rahman, Bhattacharya and Moazzem (2008) conducted a study which showed that, only 20 percent of workers are unskilled, 30 percent of workers are semi-skilled, and 44 percent of workers are skilled where the proportion of unskilled workers is quite higher in small and medium industries while the proportion of high skilled workers is higher in large industries. Besides that, Bangladesh garment workers have many issues regarding labor rights due to legal and institutional failure as most of the RMG factories often violate the labor law (Islam and Ahmed, 2010). According to Labor code from Labor Act 2006, Workers should be paid within seven working days [Section 123 (1)]. Workers 
in RMG sector do not have enough idea about the labor law as many workers in RMG are not given appointment letters and identity card at the time of their joining. Even workers are not well insured about their health and safety (Islam and Ahmed, 2010). These create unrest in RMG sector and hinder the effectiveness of RMG sector to great extent. Lower wage rate is considered as one of the core reasons behind all the labor unrest in RMG sector (Uddin and Jahed, 2007). Although reaction of the factory owners is different as they refuse all allegation about not paying on time and claim that workers get paid within $1^{\text {st }}$ and $2^{\text {nd }}$ week of the month (Rahman, Bhattacharya and Moazzem, 2008). RMG sector has emerged to create employment opportunities specially to empower women and alleviate poverty (Barua and Ansary, 2017). Although despite of being discriminated and having a lower payment, Women prefer to work in RMG sector because of their critical economic condition (Paul-Majumder, 1998). They often fail to maintain their living cost despite working overtime because of their poor salary structure which makes the RMG sector more insecure for women (Hossain et. al., 1990). In recent years, RMG sector has been facing challenges for not ensuring workplace safety for millions of garment workers which makes factories more hazardous for workers. Rana Plaza collapsed on $24^{\text {th }}$ of April 2013 is one of the most tragic incidents took place due to the violation of building construction. This issue drew global attention and had an adverse impact on RMG reputation as the GSP program of Bangladesh was suspended on 27 $7^{\text {th }}$ June 2013 (Barua and Ansary, 2017).

Despite of dealing with all these issues, recently RMG sector has stuck into the outbreak of covic-19 virus. The mass spread of this covid-19 virus throughout China and the world has been a great shock in 2019-2020 and had an adverse impact on the world's economy. At first Pneumonia appeared in south China seafood market in Wuhan, Hubei Province, China in December 2019 (Huang et.al., 2020). According to the State Council of the People's Republic of China, Soon a medical expert was sent there for an intensive investigation about the concerned matter and a novel corona virus was detected in the laboratory of Virology used as a center for Disease Control and Prevention on $7^{\text {th }}$ January 2020. Unfortunately, this virus spread throughout China before Chinese government could react and exported internationally. To prevent this virus from massive spread, Government closed all the channels of Wuhan temporarily (Yue et.at., 2020). After a ponderous destruction in Europe, first three patients of Novel corona virus including two members in one family was infected on $8^{\text {th }}$ March 2020 confirmed by the director of IEDCR Dr. Meerjady Sabrina Flora. Since the vaccine of corona virus is yet to be invented, maintaining social distance is what is needed as guided by the medical expert (IEDCR, 2020).

According to the report of Health ministry, newly 564 individuals got infected by corona virus in last 24 hours with a total number of 7667 individuals infected within $30^{\text {th }}$ April 2020. Most of the districts are locked down for the prevention of massive spread of this deadly virus. Lock down forces many industries to shut down their production suddenly as factories often violate the health safety measure guided by the labor law. There is also a health hazard for the workers those who do not take necessary precautions. This creates a temporary blow in our garments sector as many workers have become workless. Order cancellation by the brands all over the world poses a great threat to millions of workers and RMG industry of Bangladesh as reported by New York Times, the Forbes, and BBC. All this temporary shutdown creates a huge problem for the factories to arrange payment not only for the workers but also to purchase raw materials. Considering the outbreak of corona virus, all the factories will remain closed till $14^{\text {th }}$ April 2020 and all the salaries need to be paid to workers upon opening within $16^{\text {th }}$ April 2020 (BGMEA, 2020). A total number of 1144 of factories are reported to shut down their rituals entirely as 980 million pcs of export orders get cancelled within $20^{\text {th }}$ April 2020 that accounts 3.17 billion US\$. A total 2.27 million workers are directly affected with this sudden switch off the factories (BGMEA, 2020). Many factories have not been maintaining enough health care safety which keep all the workers of those factories vulnerable to covic-19 virus. Countries like China, USA, Canada, Australia are considered as an export hub for Bangladesh are hugely affected by covic-19 virus as reported by World Health Organization (WHO). The cancellation of product orders will have multiple adverse impact on RMG sector through higher cost of production, lower export earnings, wage cut, sacking from the job leading to unemployment in labor market.

Several studies have been conducted to analyze the role of RMG sector in the economy of Bangladesh. However taking note of the previous literature, this attempts to trace out the role of RMG export earnings as a dominant contributor of total export earnings and the effect of current pandemic situation in the RMG export earnings which in turn imbalance the trade balance of Bangladesh. 


\section{Methodology:}

This paper is based on secondary data extracted from different secondary sources like Bangladesh Bureau of Statistics (BBS), Bangladesh Labor Force Survey, Bangladesh Garment Manufacturing and Export Association (BGMEA), Bangladesh Export Promotion Bureau, Bangladesh Bank (BB), World Bank (WB) and relevant research articles for several years. A sample of 30 years of export data of readymade garments and total export earnings of Bangladesh has been used to find out the relationship between total export earnings and RMG export earnings of Bangladesh by using simple regression analysis through SPSS program. Correlation between RMG export earnings and total export earnings has been found through Pearson correlation test.

\section{Hypothesis:}

$\mathrm{H}_{0}$ : There is no significant relationship between RMG export earnings \& total export earnings.

$\mathrm{H}_{1}$ : There is a significant relationship between RMG export earnings \& total export earnings.

\section{The Export earnings scenario of Bangladesh:}

Balance of payment exhibits the epitome of all the transactions held between Bangladeshis and foreign residents within a given period, particularly a year. Balance of payment consisting current account and capital account shows the country's export-import trade data and capital inflow-outflow that directly affect the nation's foreign assets and liabilities, respectively. In current account segment, balance of trade has been registered to show the differences between total export and total import of a country. The value of export higher than the value of import generates a surplus trade balance where higher value of import over export generates a deficit trade balance (Nargis \& Nusrat, 2013).

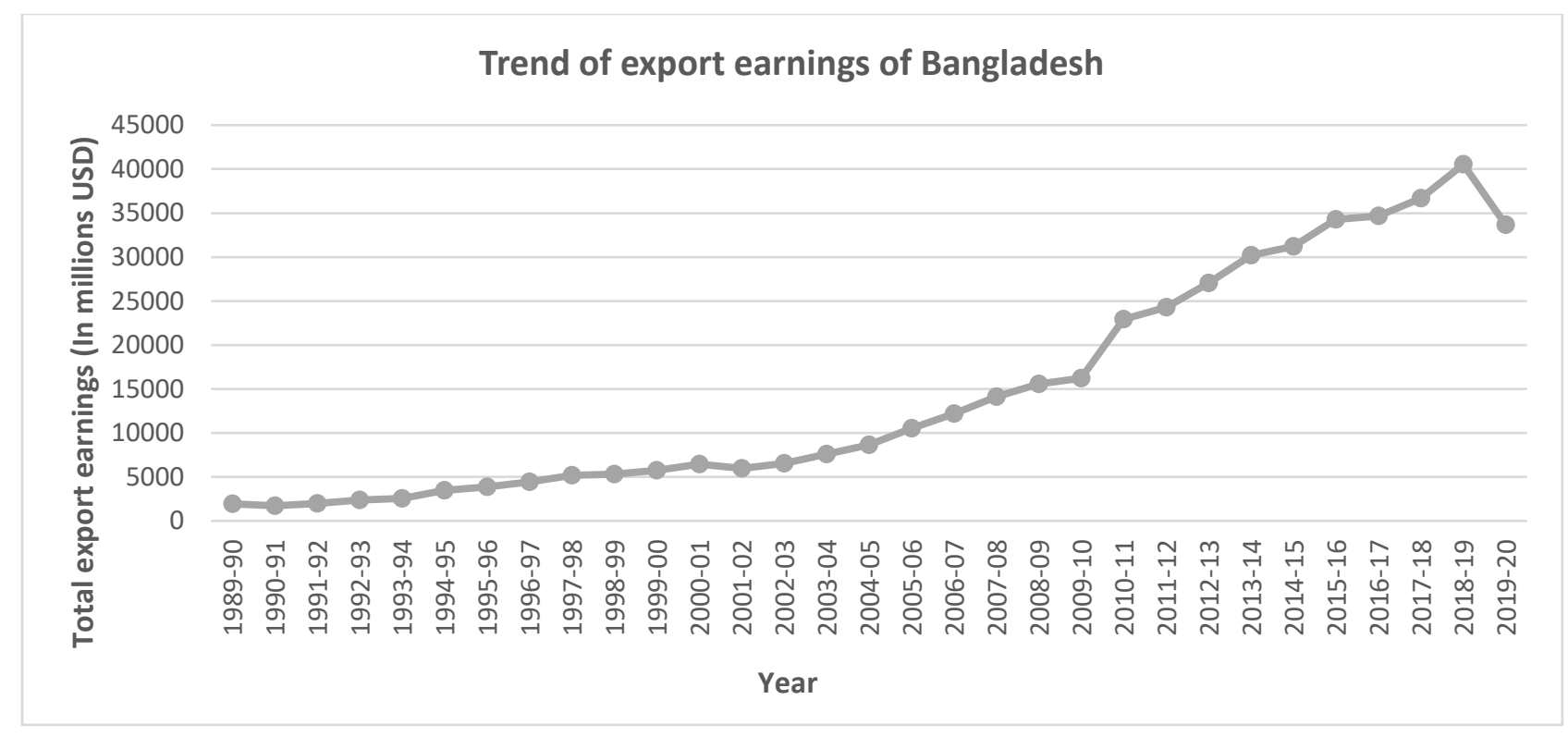

Source: BGMEA, Bangladesh Bureau of Statistics (2019)

Figure 01: Trend of export earnings of Bangladesh

Bangladesh is considered as one of rising developing economies with its huge potential sources of export earnings. The trend of export earnings has shown a positive trend for last 30 years was 1923.7 billion USD in 1989-90 took a gradual uprise. Initially the export growth rate showed a steady rise for at least 10 years suddenly found its gear from 2002-03. Introduction of various export-oriented products along with a boom of RMG sector pushes the export earnings of Bangladesh (Bangladesh Bureau of Statistics, 2019). Figure 01 shows the gradual increase in the trend of export earnings of Bangladesh with its tiny ups and downs due to economic downturn and export growth rate rose in a substantial manner for last 10 to 15 years. 


\section{The growth of Ready-made garments sector of Bangladesh:}

Developing countries are recognized as a potential source of cheap labor for developed countries. Bangladesh with its huge population size and surplus labor supply attracts foreign buyers from many developed countries. RMG sector has been considered as one of the leading sources of export earnings as well as prime source feeding surplus labor. The journey of RMG sector started in 1970 as non-traditional sector were reached to 4.5 billion USD export earnings which put a strong foundation of RMG sector (Adnan et.at., 2015). The growth of the RMG sector helped to have a positive effect on macroeconomic balances along with maintaining a sustainable trade deficit (Rahman, 2002).

Table 01: Growth of RMG export trend as a percentage of National export

\begin{tabular}{|c|c|c|c|c|}
\hline Year & $\begin{array}{c}\text { Number of Garment } \\
\text { factories }\end{array}$ & $\begin{array}{c}\text { Employment in million } \\
\text { workers }\end{array}$ & $\begin{array}{c}\text { Export of RMG } \\
\text { (In million USD) }\end{array}$ & $\begin{array}{c}\% \text { of RMG to } \\
\text { National export }\end{array}$ \\
\hline $1989-90$ & 759 & 0.34 & 624.16 & 40.96 \\
\hline $1990-91$ & 834 & 0.40 & 866.82 & 50.47 \\
\hline $1991-92$ & 1163 & 0.58 & 1182.57 & 59.31 \\
\hline $1992-93$ & 1537 & 0.80 & 1445.03 & 60.64 \\
\hline $1993-94$ & 1839 & 0.82 & 1555.78 & 61.4 \\
\hline $1994-95$ & 2182 & 1.2 & 2228.35 & 64.17 \\
\hline $1995-96$ & 2353 & 1.29 & 2547.13 & 65.61 \\
\hline $1996-97$ & 2503 & 1.3 & 3001.4 & 67.93 \\
\hline $1997-98$ & 2726 & 1.5 & 3783.63 & 73.31 \\
\hline $1998-99$ & 2963 & 1.5 & 4020.23 & 75.67 \\
\hline $1999-00$ & 3200 & 1.6 & 4352.39 & 75.66 \\
\hline $2000-01$ & 3480 & 1.8 & 4860.12 & 75.15 \\
\hline $2001-02$ & 3618 & 1.8 & 4583.8 & 76.57 \\
\hline $2002-03$ & 3760 & 2 & 4912.1 & 75.01 \\
\hline $2003-04$ & 3957 & 2 & 5686.09 & 74.79 \\
\hline $2004-05$ & 4107 & 2.1 & 6417.67 & 74.15 \\
\hline $2005-06$ & 4220 & 2.2 & 7900.8 & 75.06 \\
\hline $2006-07$ & 4490 & 2.4 & 9211.23 & 75.64 \\
\hline $2007-08$ & 4743 & 2.8 & 10699.8 & 75.83 \\
\hline $2008-09$ & 4925 & 3.5 & 12347.77 & 79.33 \\
\hline $2009-10$ & 5063 & 3.6 & 12496.72 & 77.12 \\
\hline $2010-11$ & 5150 & 3.6 & 17914.46 & 78.15 \\
\hline $2011-12$ & 5400 & 4 & 19089.69 & 78.6 \\
\hline $2012-13$ & 5876 & 4 & 21515.73 & 79.61 \\
\hline $2013-14$ & 4222 & 4 & 24491.88 & 81.13 \\
\hline $2014-15$ & 4296 & 4 & 25491.4 & 81.68 \\
\hline $2015-16$ & 4328 & 4 & 28094.17 & 82.01 \\
\hline $2016-17$ & 4482 & 4 & 28149.84 & 81.23 \\
\hline $2017-18$ & 4560 & 4 & 30614.76 & 83.49 \\
\hline Soure & 4 & & \\
\hline
\end{tabular}

Source: EPB, Bangladesh Bank, Compiled by BGMEA, 2019

Table 01 exhibits the evolution of RMG sector as a potential sources of export earnings of Bangladesh. Establishment of various number of factories provided a massive fuel into the production of diversified RMG products. Starting from 759 number of factories in 1989-90 had shown a gradual increase in various factories which has reached to a total 4560 number of RMG factories in 2017-18. RMG sector has been providing number of employment opportunities for both skilled and unskilled labor force. There has been a huge dominance of female workers in RMG sectors with very poor educational qualification. Over 4 million labor force are active in readymade garment industries in 2017-18 fiscal year (BGMEA, 2019). 


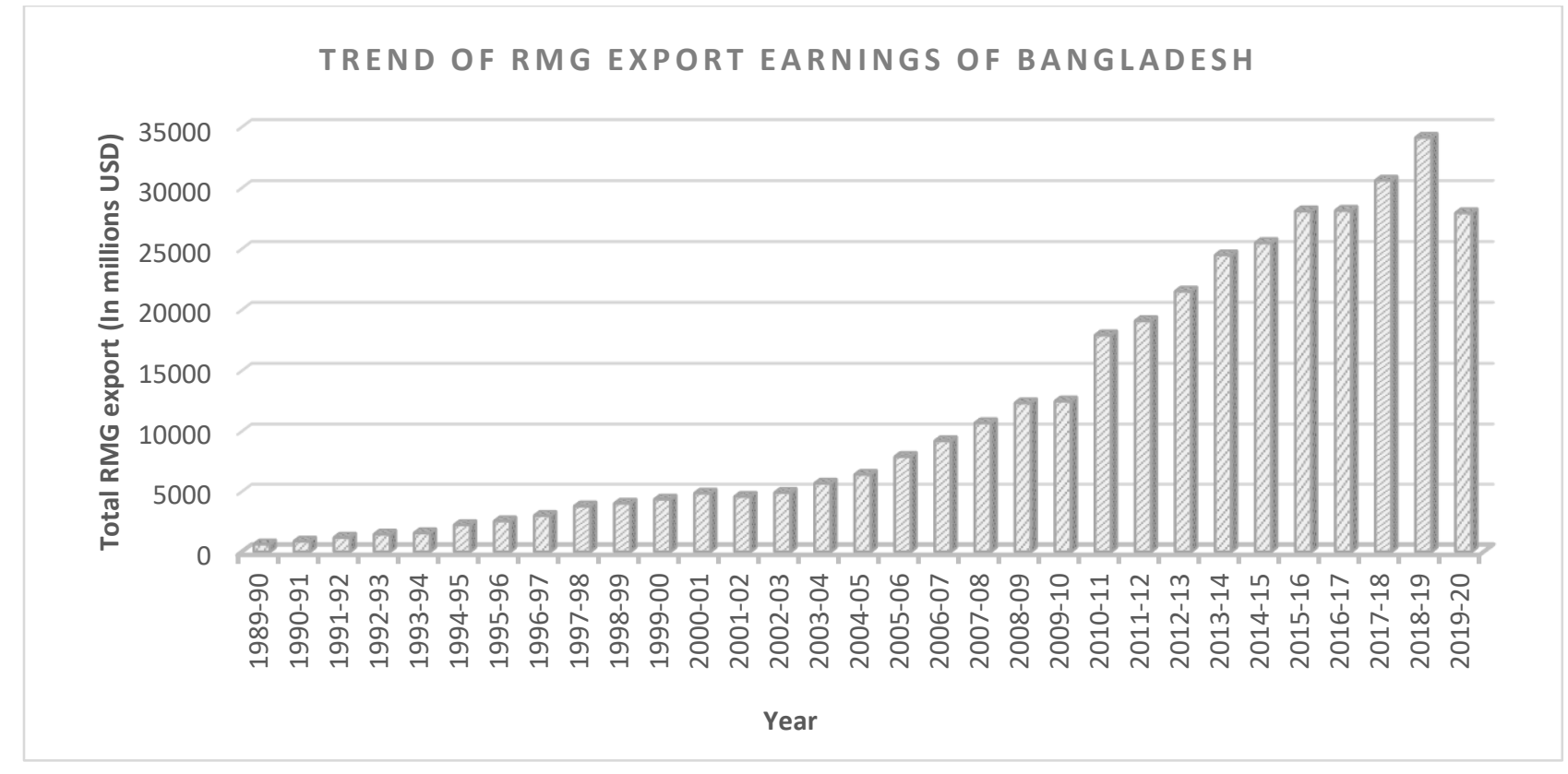

Source: BGMEA, Bangladesh Bureau of Statistics (2019)

Figure 02: Trend of RMG export earnings of Bangladesh

Export earnings of RMG has been increasing over the period which contributes a lot to the national export earnings of Bangladesh. The substantial positive export growth rate of RMG sector can be seen from figure 02 which constitute a greater percentage of total export earnings of Bangladesh. According to Export Promotion Bureau (2019), total export earnings of readymade garments is estimated to be 30614.76 million USD which is 83.49 percent of the total export earnings of Bangladesh.

Table 02: Bangladesh's RMG export to major countries

\begin{tabular}{|c|c|c|c|c|}
\hline \multirow{2}{*}{ Countries } & \multicolumn{3}{|c|}{ Total Export earnings (In million USD) } & \multirow{2}{*}{$\begin{array}{c}\text { Growth rate } \\
\end{array}$} \\
\cline { 2 - 4 } & $(2017-18)$ & $(2018-19)$ & $(2019-20)$ & -16.09 \\
\hline USA & 5352.07 & 6133.72 & 5146.53 & -17.94 \\
\hline Germany & 5579.51 & 5840.91 & 4793.03 & -17.77 \\
\hline UK & 3724.26 & 3859.15 & 3173.23 & -16.12 \\
\hline Spain & 2277.77 & 2407.13 & 2019.21 & -25.7 \\
\hline Canada & 963.15 & 1179.3 & 876.27 & -14.86 \\
\hline Netherland & 935.38 & 1024.46 & 872.21 & -8.71 \\
\hline Poland & 864.85 & 1180.88 & 1077.98 & -11.86 \\
\hline Japan & 846.74 & 1091.43 & 961.94 & -16.48 \\
\hline Australia & 634.01 & 719.78 & 601.14 & -9.76 \\
\hline Russia & 427.93 & 488.58 & 440.88 & -34.86 \\
\hline China & 391.64 & 506.51 & 329.96 & -15.7 \\
\hline India & 278.68 & 499.09 & 420.73 & -33.57 \\
\hline Brazil & 158.38 & 160.51 & 106.63 & -18.3 \\
\hline Mexico & 148.35 & 203.73 & 166.45 & \\
\hline
\end{tabular}

Source: Export Promotion Bureau, compiled by BGMEA, 2019

Table 02 forecasts top RMG export destination of Bangladesh with the export growth rate of RMG in 2019-20 fiscal year. USA, Germany, UK, Spain are the most important source of RMG export of Bangladesh. Canada, Netherland 
along with other European countries have shown lot of interest in this sector. In 2019-20, The negative growth of the RMG export earnings from top RMG export destination is a clear indication of its recent performance due to economic downturn.

\section{Data analysis:}

Table 03: Relationship between total export earnings \& RMG export earnings

\begin{tabular}{|c|c|c|c|}
\hline \multicolumn{4}{|c|}{ Correlations } \\
\hline \multirow{3}{*}{ RMG export } & Pearson correlation & RMG export & Total export \\
\cline { 2 - 4 } & Sig. (2-tailed) & 1 & $1.000 * * *$ \\
\hline \multirow{nyyy}{*}{ Total export } & $\mathrm{N}$ & 31 & .000 \\
\cline { 2 - 4 } & Pearson correlation & $1.000 * * *$ & 31 \\
\cline { 2 - 4 } & Sig. (2-tailed) & .000 & 31 \\
\hline
\end{tabular}

\begin{tabular}{|c|c|c|c|c|c|c|c|}
\hline \multicolumn{8}{|c|}{ Model Summary } \\
\hline Model & \multicolumn{2}{|c|}{$\mathrm{R}$} & R Square & \multicolumn{2}{|c|}{ Adjusted R Square } & \multicolumn{2}{|c|}{ Std. Error of the estimate } \\
\hline 1 & \multicolumn{2}{|c|}{$1.000^{\mathrm{a}}$} & 0.999 & \multicolumn{2}{|c|}{.999} & \multicolumn{2}{|c|}{387.99234} \\
\hline \multicolumn{8}{|c|}{$\begin{array}{l}\text { a. Predictors: (Constant), RMG export } \\
\text { b. Dependent variable: Total export }\end{array}$} \\
\hline \multicolumn{8}{|c|}{ Coefficients $^{\text {a }}$} \\
\hline \multirow[b]{2}{*}{ Model 1} & \multicolumn{2}{|c|}{$\begin{array}{l}\text { Unstandardized } \\
\text { Coefficient }\end{array}$} & $\begin{array}{l}\text { Standardized } \\
\text { Coefficients }\end{array}$ & \multirow[b]{2}{*}{$\mathrm{t}$} & \multirow[b]{2}{*}{ Sig. } & \multicolumn{2}{|c|}{$\begin{array}{l}95 \% \text { confidence interval } \\
\text { for B }\end{array}$} \\
\hline & $\mathrm{B}$ & Std. Error & Beta & & & $\begin{array}{l}\text { Lower } \\
\text { bound }\end{array}$ & $\begin{array}{l}\text { Upper } \\
\text { bound }\end{array}$ \\
\hline (Constant) & 880.072 & 104.217 & \multirow[b]{2}{*}{1.000} & 8.445 & .000 & 666.926 & 1093.219 \\
\hline RMG export & 1.189 & 0.007 & & 179.222 & .000 & 1.175 & 1.202 \\
\hline
\end{tabular}

The value of B for RMG export of Bangladesh is 1.189 apprises that one-unit change in the independent variable (RMG export) will lead to 1.189-unit change in dependent variable (Total export). Total export earnings are affected about 99 percent by the change in RMG export earnings which is acquainted by the value of $R^{2}$. The value of $R$ explains that Total export earnings and RMG export earnings are 100 percent correlated. The P-value is less than 0.01 which means that null hypothesis can be rejected, and we can state that- there is a significant relationship between total export earnings and RMG export earnings of Bangladesh. 


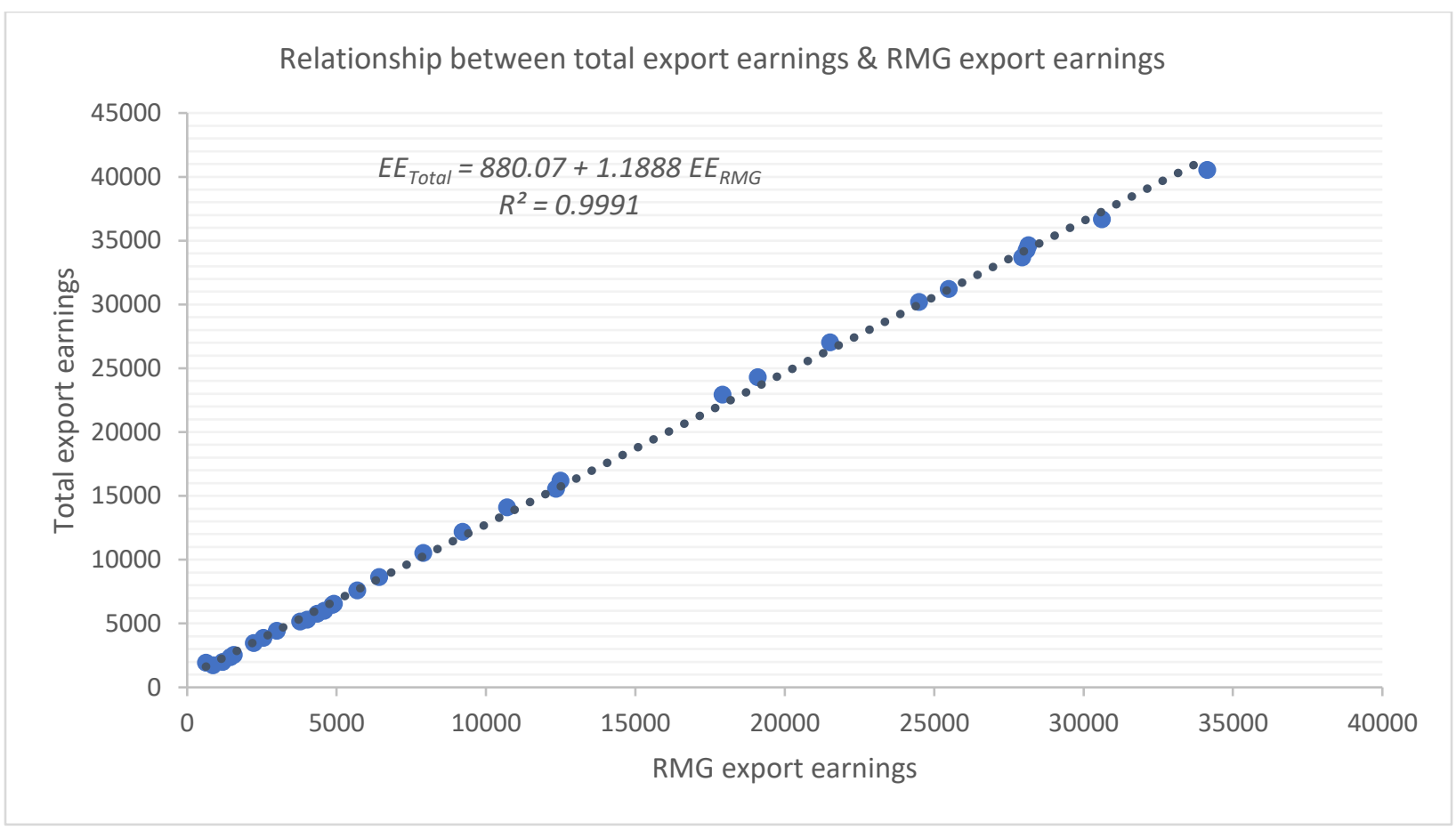

Source: EPB, Bangladesh Bank, Compiled by BGMEA, 2019

Figure 03: Relationship between Total and RMG export earnings

Figure 03 shows a strong relationship between total export earnings and RMG export earnings of Bangladesh through Pearson correlation analysis. The correlation is significant at 0.01 level (2-tailed). The trend line also suggests the strong dependency of total export earnings on the RMG export earnings.

\section{Impact of COVID-19 on the Trade balance and RMG export:}

Over the last decade the growth of the RMG sector was almost more than 25 percent which is under the threat of losing its significant portion of market share due to the issues of safety, health, and welfare of the workers. These compliance issues may hamper the job creation nature of the RMG sector (Rashid et. al., 2013). Community transmission of corona virus has added some new challenges in RMG sector.

Massive spread of COVID-19 has an adverse impact on the economy of many developed countries which effects the export earnings of many countries like Bangladesh. Bangladesh has been incorporating with trade deficit every year. Recent pandemic situation has made it worse than before due to the lockdown situation in many developed countries. 


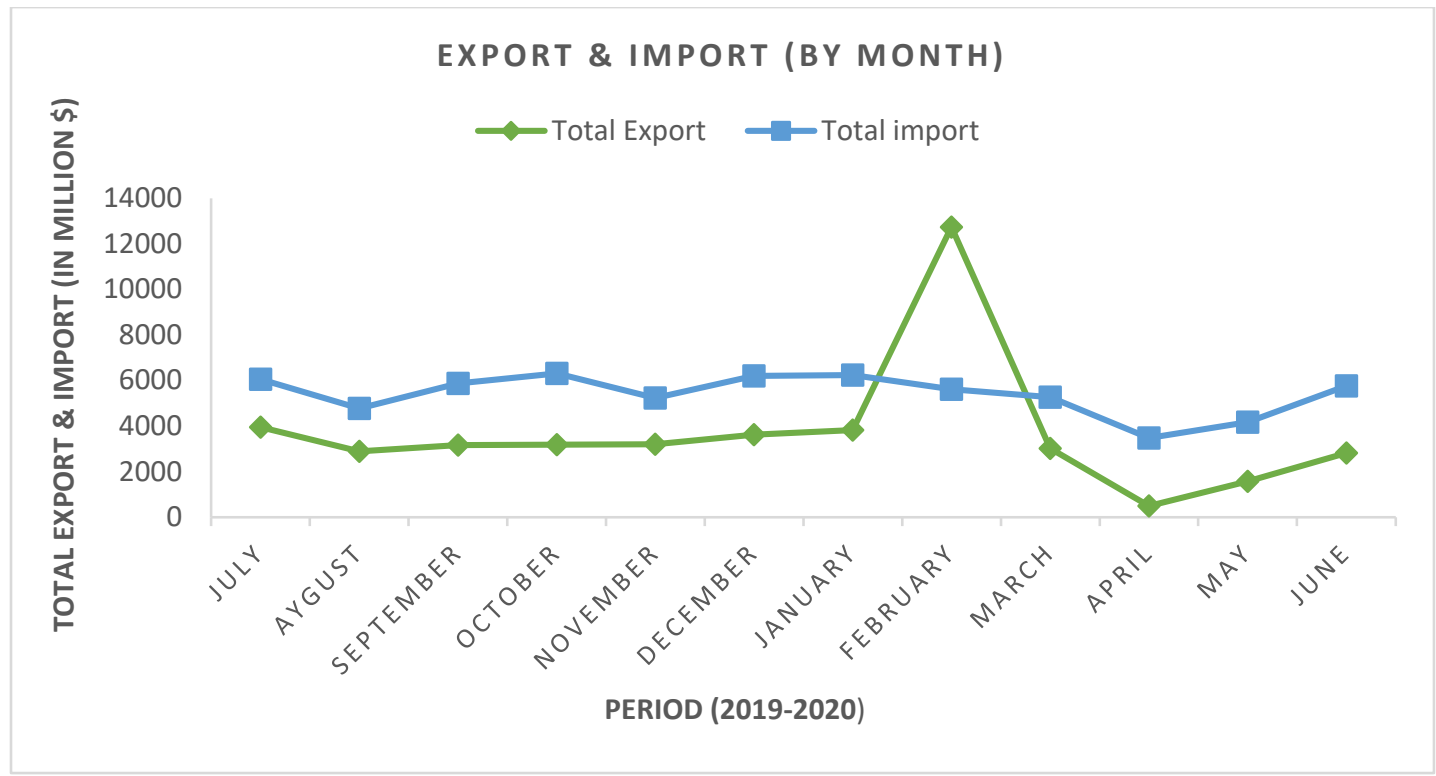

Source: Bangladesh Bureau of Statistics (BBS), 2020

Figure 04: Total export and import (By month)

In figure 04, a monthly export and import data is given to show the trend of export and import of Bangladesh for last twelve months. Despite of having trade deficit, Bangladesh has managed to receive a trade surplus in February 2020. But there is a huge trade deficit especially from March 2020 to June 2020 which makes the balance of trade more vulnerable.

Table 04: Bangladesh's RMG export to World: FY 2018-19 \& 2019-20

\begin{tabular}{|c|c|c|c|}
\hline & $\begin{array}{c}\text { Total export (Woven+ Knit) } \\
\text { Months }\end{array}$ & $\begin{array}{c}\text { Total export (Woven+ Knit) } \\
2019-20\end{array}$ & Growth rate (\%) \\
\hline July & 3017.74 & 3310.48 & 9.7 \\
\hline August & 2717.42 & 2406.01 & -11.46 \\
\hline September & 2456.51 & 2341.07 & -4.7 \\
\hline October & 3141.42 & 2519.82 & -19.79 \\
\hline November & 2853.11 & 2511.31 & -11.98 \\
\hline December & 2898.71 & 2935.33 & 1.26 \\
\hline January & 3132.57 & 3039.22 & -2.98 \\
\hline February & 2908.87 & 2784.28 & -4.28 \\
\hline March & 2825.07 & 2256.2 & -20.14 \\
\hline April & 2539.28 & 374.67 & -85.25 \\
\hline May & 3243.18 & 1230.54 & -62.06 \\
\hline June & 2399.39 & 2240.26 & -6.63 \\
\hline
\end{tabular}

Source: Export Promotion Bureau (EPB), 2019-20

Table 04 provides a brief view on the RMG export earnings for last twelve months. The negative growth rate of RMG export earnings raises a huge concern for the economy of Bangladesh. The significant insight of the analysis is the fact that, There is a significant negative export growth rate of RMG export earnings as only 1144 factories are reported active during the lockdown situation which leads to a cancellation of 980 million pcs of RMG products worth 3.17 
million USD export loss within $20^{\text {th }}$ April 2020 (BGMEA, 2020). These imbalances in RMG export earnings also introduce a great panic in the total export earnings of Bangladesh during this pandemic outbreak. Shutdown of many factories during this time also creates a huge panic in the labor marker as 2.27 million RMG workers are directly or indirectly affected through cutting down their salaries or loss of their job permanently. COVID-19 outbreak adversely affects the export earnings of RMG industry which creates a massive pressure in the total export earnings of Bangladesh.

\section{Recommendations:}

Readymade garment sector constitutes a potential source of export earnings of Bangladesh which has been adversely affected by the massive spread of COVID-19. Lockdown situation of many developed countries has turned the situation worse for many developing countries. RMG sectors being the dominant source of export earnings of Bangladesh needs to be taken care of to ensure a smooth trade balance of the economy of Bangladesh. This paper recommends some strategies can be implemented to find some way to defend the situation for the long-term benefit of the country's trade balances:

i. Export diversification need to be developed to seek for diversified export-oriented products to ensure a smooth trade balance.

ii. Worker's safety needs to be ensured through disbursing their wages as RMG sector provides an important source of employment opportunities for many cheap workers.

iii. Responsible long-term partnership needs to be developed where purchasing practice should provide much clarity to ensure worker's fundamental rights.

iv. Government needs to provide some sort of incentive scheme to those RMG factories shut down during the lockdown situation to attract the foreign buyers and generates more employment opportunities.

v. Concerned authorities should generate enough health security to RMG workers to ensure their effective and safe participation in the workplace.

\section{Conclusion:}

Readymade garment industry has been generating the fuel to the economy of the country like Bangladesh. Readymade garment which constitutes the major portion of total export earnings of Bangladesh has been facing a critical situation with the introduction of COVID-19 outbreak which creates a pandemic situation to overall economy of Bangladesh. The export earnings of RMG sector having faced a great deal of difficulties also pushes the differences between export and import generating a greater trade deficit (EPB, 2020). There has been an adverse effect of the deterioration of export earnings due to loss of export demand from many European giants which lead to a huge loss of employment opportunities for many labors engaged in readymade garment industry as 1144 factories are shut down during the pandemic situation (BGMEA, 2020). Effective policies can only solve the negative export growth rate of RMG sector to complement the trade balance of Bangladesh.

\section{References:}

Adnan, A. T. M., Rakib, A., \& Rahman, M. (2015). Export trend of Bangladesh: The dominance of ready-made garment industry. Research Journal of Economics, Business, and ICT, 10(1).

Akhter, S., Salahuddin, A. F. M., Iqbal, M., Malek, A. B. M. A., \& Jahan, N. (2010). Health and occupational safety for female workforce of garment industries in Bangladesh. Journal of Mechanical Engineering, 41(1), 65-70.

Ansary, M. A., \& Barua, U. (2015). Workplace safety compliance of RMG industry in Bangladesh: Structural assessment of RMG factory buildings. International Journal of Disaster Risk Reduction, 14, 424-437.

Asian Development Bank Annual Reports, Various Economic and Sectoral Reports.

Barua, U., \& Ansary, M. A. (2017). Workplace safety in Bangladesh ready-made garment sector: 3 years after the Rana Plaza collapse. International Journal of Occupational Safety and Ergonomics, 23(4), 578-583.

Bhattacharya, D., Rahman, M., \& Raihan, A. (2002). Contribution of the RMG Sector to the Bangladesh Economy. CPD Occasional Paper Series, 50(6). 
Bangladesh Bureau of Statistics-BBS (2019), Report on Bangladesh Sample Vital Statistics 2018 \& 2019, Ministry of Planning, Government of Bangladesh.

Bangladesh Garment Manufacturers and Exporters Association (BGMEA) (2020). Trade Information. Retrieved from http://www.bgmea.com.bd/home/pages/tradeinformation\#.VXrqCaZ vDl4

Chowdhury, M., Ahmed, R., \& Yasmin, M. (2014). Prospects and Problems of RMG Industry: A study on Bangladesh. Prospects, 5(7), 103-118.

Chowdhury, M. A. M., Ali, M. M., \& Rahman, R. (2006). WTO, post-MFA era and the Bangladesh RMG sector: An assessment of performance and challenges. South Asian Journal of Management, 13(1), 76.

Dina, I. J. BANGLADESH GARMENT MANUFACTURERS AND EXPORTERS'ASSOCIATION (BGMEA).

Export Promotion Bureau, Export Promotion Bureau, Bangladesh: Ministry of Commerce, Statistical Details,2020, Available at: (http://www.epb.gov.bd/in dex.php/home/export data analysis)

Hossan, C. G., Sarker, M. A. R., \& Afroze, R. (2012). Recent unrest in the RMG sector of Bangladesh: is this an outcome of poor labour practices? International Journal of Business and Management, 7(3), 206.

Huang, C., Wang, Y., Li, X., Ren, L., Zhao, J., Hu, Y., ... \& Cheng, Z. (2020). Clinical features of patients infected with 2019 novel coronavirus in Wuhan, China. The Lancet, 395(10223), 497-506.

Hasan, M. T. (2020). Addressing the COVID-19 related stigma and discrimination: a fight against infodemic in Bangladesh.

Islam, M. S., and Ahmed, S. (2010). Contemplating Sustainable Solutions to Garments Sector Unrest. The Daily Star, 10 July.

Nargis, N. (2013). An analysis of export and import growth of Bangladesh: A study on ready-made garment (RMG).

Rashid, M. M., Ahmad, S., \& Sarkar, M. R. (2014). Compliance of safety, health, and welfare in RMG of Bangladesh. Technology (BUET), 1877, 7058 .

Rehman S., \& Khundker N. (Eds.) (2001). Globalization and Gender, Changing Patterns of Woman's Employment in Bangladesh, Centre for Policy Dialogue, University Press Limited, Dhaka.

Robbani, M. G. (2000). World Trade Organization and the Ready-Made Garment Industry of Bangladesh: A Critical Analysis. Journal of Business Studies, 2(2), 16-27.

Rock, M. (2001). Globalization and Bangladesh: The Case of Export Oriented Garment Manufacture. South Asia, 24(1), 201-225. doi: $10.1080 / 00856400108723430$

Rahman, M. (2002). Bangladesh's External Sector in FY 2001: Review of Performance and Emerging Concerns. In R. Sobhan (Ed.), Bangladesh Facing the Challenges of Globalization: A Review of Bangladesh's Development, Centre for Policy Dialogue, Dhaka.

Rahman, Mustafizur, Bhattacharya, Debapriya and Moazzem, Khondaker Golam. (2008). Bangladesh Apparel Sector in Post MFA Era: A Study on the Ongoing Restructuring Process. Dhaka: Centre for Policy Dialogue in association with IFC and SEDF.

Uddin, M.S., and Jahed, M.A. (2007). Garments Industry: A Prime Mover of the Social Economic Development of Bangladesh. The Cost and Management, 35(1): 59-70.

Yunus, M., \& Yamagata, T. (2012). The garment industry in Bangladesh. Dynamics of the Garment Industry in Low-Income Countries: Experience of Asia and Africa (Interim Report). Chousakenkyu Houkokusho, IDE-JETRO, 6, 29. 